\title{
Differentiation of Traditional Frozen Food of Uli Ketan by Addition of Kidney Beans and Oyster Mushroom Filling
}

\author{
Dede Irma Suryani, Woro Priatini
}

Indonesia University of Education, Jl. Dr. Setiabudhi No. 229, Bandung 40154, Indonesia

*Corresponding Author. E-mail: ddirmasuryani@student.upi.edu (Dede Irma Suryani)

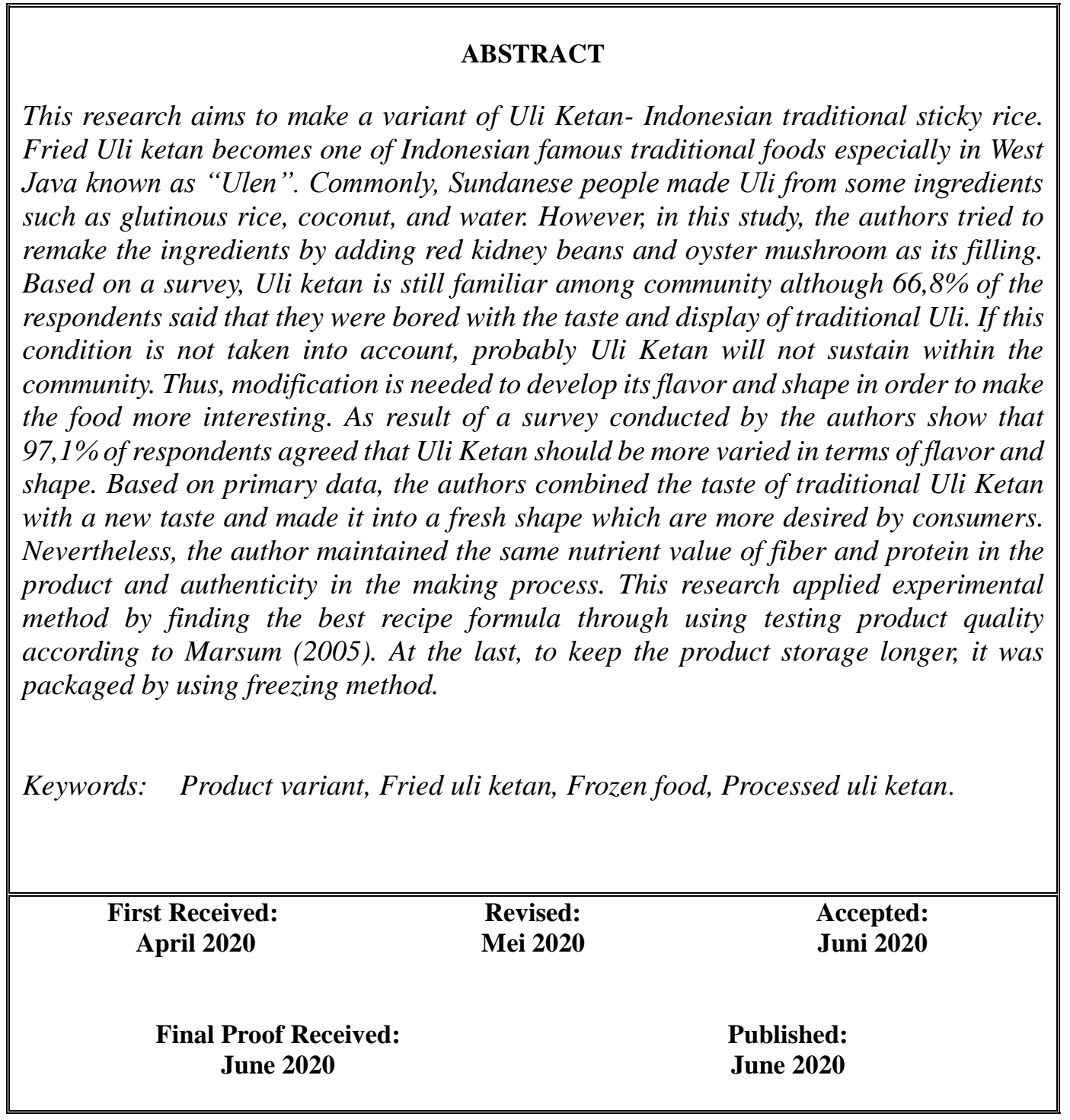




\section{Introduction}

Tourism is the second foreign exchange earner after palm oil in Indonesia. The tourism sector has a significant impact on the country's economy. This is inseparable from human needs for tourism globally, not only in Indonesia, but also throughout the world. The growing need for tourism makes the tourism sector considered to have great prospects in the future. Tourism is divided into several types, one of which is gastronomic tourism.

Hall, Mitchell (2005) and Green, Dougherty (2008) (in Katsoni, 2019) state that gastronomic tourism is a pursuit of unique experiences in eating and drinking. Gastronomic tourism generally refers to the authenticity of a food and it becomes characteristic of a place, the territory of a country, covering the main area from which food tourism originates (p. 102). Based on the description, gastronomic tourism refers to the typical food of an area or in Indonesia known as traditional food. Traditional food is food that has existed since the days of ancestors and the process is hereditary. Usually, traditional foods use simple cooking techniques. Traditional foods, according to Intani (2006), are foods that are created and developed in their respective environments (p. 186). One of the foods that exist until now is uli ketan.

Uli ketan is a snack made from steamed sticky rice and then pounded until sticky so it can be formed. Uli ketan is still known by the general public. However, the lack of product development makes uli ketan one day can be eliminated with other products. Based on survey data on the saturation of sticky rice, the following results were obtained.

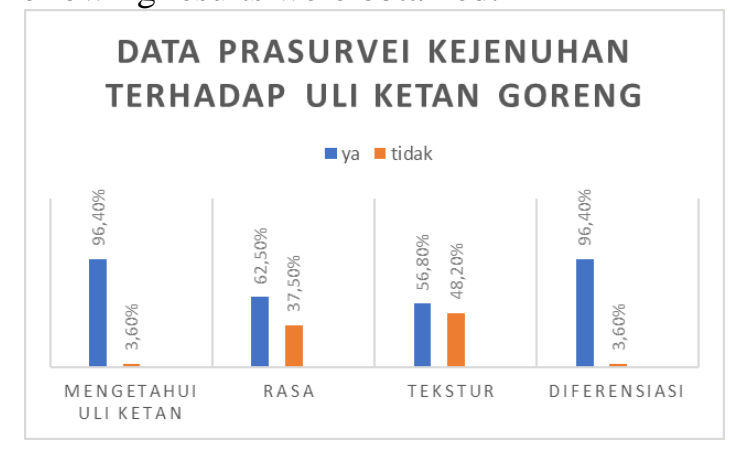

Figures 1. Survey data of fried uli ketan saturation

The community has begun to consider the taste of monotonous rice cake. At the same time the public wants product differentiation so that it becomes a different product and is expected to be better. This strengthens that uli ketan must undergo development so that it becomes even better. Based on these descriptions, the author will conduct research into the manufacture of products by finding the best recipe formula. The author conducted this research with the title "Differentiation of Traditional Uli Ketan Goreng Goreng with the addition of Red Beans and Oyster Mushroom Filling".

\section{Literature Review}

\subsection{Gastronomy}

The term gastronomy is known since the 4th century BC in Ancient Roman times. Furthermore, it was investigated as a term in the 18th century. Gastronomy explains the relationship between food consumed by humans, namely gastro (digestion) and nomi (law).

According to Hall et al (2006), gastronomic tourism is a food search trip to an area with recreational purposes, including visiting major and second food producers, food festival events, farmers markets, cooking and demonstration events, and tasting quality food products and tourism activities. related to food. In other words, food tourism provides experiences, results from learning processes of different cultures (pp. 9-10).

According to Turgarini (2016), gastronomic tourism is a journey taken by someone with high motivation for food and drink in an area. Almost all activities are carried out based on existing interests in tourists. (p. 91)

Based on these descriptions, it can be concluded that gastronomic tourism is a travel activity to enjoy food or drinks in a place of interest in someone.

\subsection{Traditional Food}

Muhilal (in Moeriabrata, 1997: 3) states that "traditional food is food that has existed since the ancestors of the archipelago and this traditional food has been entrenched in the local community".

According to Intani (2006) traditional foods are foods that are created and developed in their respective environments (p. 186). Based on this statement, traditional food is food that has existed since the ancestors and preservation for generations. Usually, traditional foods use simple cooking methods, such as boiling, steaming, drying, etc., making traditional foods 
healthier.

\subsection{Uli ketan}

Uli ketan is a traditional food made from glutinous rice which is steamed, pounded until smooth, shaped, and dried with the help of sunlight. This uli ketan is usually baked and served with oncom sauce, some are fried rice kettle. In the writer's area, uli ketan is fried and used as a snack to accompany a cup of coffee or warm sweet tea.

According to Wira Herdiyansyah, uli ketan started from the Majapahit Kingdom in Indonesia. It has a romantic philosophy because in its making there is a division of tasks between women and men. In making sticky rice, men are tasked to pound sticky rice, while women shape and cook until sticky rice becomes sticky rice that can be served. The division of tasks makes a strong bond of togetherness, such as the sticky rice properties that stick together from each other after being forged dozens of times. The more forged the stronger and more unified bond. Sticky rice has a high gluten content so that, when cooked, it sticks together with one another. It is a symbol of inter-community attachment.

The basic ingredients of glutinous rice are white glutinous rice or Oryza sativa glutinosa. Glutinous rice has a sticky texture when cooked. This is caused by the content of starch whose amylopectin content is higher than the amylose content. According to Priyanto (in Suriani, 2015: 93), "the biggest compiler of glutinous rice is amylopectin by $88 \%-89 \%$, while amylose is only about $1 \%-2 \%$. Both of these substances make the texture of rice to be sticky, fluffier, or pera ".

\subsection{Kidney Beans}

Kidney beans are one of the beans that have a nutritional appeal in almost the European Continent, as well as in Indonesia. Red beans grow in tropical and subtropical countries, such as China, Turkey, India, Egypt, Morocco, Italy, Mexico, Spain, Brazil, Myanmar, United State, Tanzania, Uganda, Kenya, Argentina, and others (S.kumar et al. , 2013, p. 1).

Besides having a high protein content, kidney beans have a high lectin content. This lectin cannot be digested in the body. When consumed in large quantities, this lectin will reduce the body's ability to absorb nutrients. The nature of lectin that can bind to sugar makes lectin often referred to as antinutrient. In addition, the proteases present in kidney beans can cause allergies. According to Bender (2017) also states that "only three varieties of phasheolus vulgaris, namely red and white kidney beans and the rose coco beans, contained large amounts of lectins relative to the amounts found in the other six types eximined (Table 2.2)". (p. 16)

Need to do an action before cooking red beans, such as soaking overnight. This is done to reduce levels of toxins and lectins. Bender (2017) states that

Soaking overnight (16-18 h) removed varying amounts of lectins so that it would not be possible to estimate the amount left in beans eaten raw if they had, as usual, been soaked first. The garden pea, for example, lost 65 per cent of the lectin content while the three samples of red kidney beans lost between 20 per cent and 70 per cent of their original content. (p. 17).

\subsection{Oyster mushroom}

Oyster mushroom or Pleurotus astreatus belongs to the group of edible mushrooms. Oyster mushrooms have a common characteristic, such as oyster shells that widen round or half round. In addition, the ends near the stems are concave, white to beige. Oyster mushrooms originated from mainland China, then spread throughout the world, except the Pacific Northwest and often called cascadia in western North America because it has an arctic climate. Oyster mushroom cultivation was successful on a large scale in Germany during World War I. This resulted in Germany successfully alleviating the problem of poverty (Piska, 2016, p. 151).

The specialty of oyster mushrooms is it contains beta-glucans and has antioxidant activity. Beta-glucans function as an immunomodulator by stimulating the body's defense system by activating macrophages to capture and destroy foreign matter in the body, such as viruses, bacteria, fungi, and parasites. Processed food oyster mushrooms as an alternative fulfillment of nutrients because they contain fiber, protein / amino acids, carbohydrates, minerals, fats, and beta-glucans. (Astuti, 2013, p. 1)

The nutritional value of mushrooms is comparable to eggs, milk and meat. Pleurotus (oyster mushroom) species are rich sources of protein, minerals $(\mathrm{P}, \mathrm{Ca}, \mathrm{Fe}, \mathrm{K}$, and $\mathrm{Na})$, and vitamins (thiamine, riboflavin, folic acid, and 
niacin).

\subsection{Recipe Formulation}

John Birchfield (2006) states that recipe formulation is a standard by which to produce a food or drink, explaining the ingredients needed, quantity used, preparations made, portion sizes, tools needed, garnishes, and other information needed for food manufacturing. The recipe is necessary, must be understood, and followed because it is a communication tool that explains all the instructions about how to cook (p. 16).

Recipe formula is the most important part of a food. The recipe formula specifically describes the amount of food that is precise and measurable and the method of preparation that is consistent so as to produce high-quality food products, the right procedures, the type of equipment, the amount, and the quality of the ingredients used. (Christine Brown, 2014, p. 133)

Recipe formula is a very important factor in maintaining the quality of food production. "In food production, the most important control device is the recipe standard. Recipe standards include ingredients, procedures, and all information needed to prepare food. " (Payne et al., 2009, p. 256).

\subsection{Product Quality}

To determine whether a product is good or not, we need a tool, namely product quality. Product quality according to Kotler (2009), namely the totality of features and characteristics of products or services that depend on their ability to satisfy stated or implied needs (p. 143). Product quality is a potential weapon to beat competitors. Product quality is a product characteristic that is made in accordance with the measurement standards so that the more appropriate the standard of a product will be judged to be more quality (Handoko, 2002, p. 23). Product quality is very dependent on the ingredients used. Materials used in good condition will produce good output too.

Assuari (in Arumsari, 2012: 45) states that product quality is a collection of factors that make the product in accordance with the objectives for what the product is intended. This shows that a product is said to be of quality because certain factors are adjusted to the standards that make the product can achieve good quality. There are several factors that affect product quality.

According to Marsum (2005), there are several attributes or dimensions that must be considered in maintaining product quality.

a. Flavor (Taste)

Taste is an important tool in product quality. Good and distinctive taste will be the main strength in maintaining product quality.

b. Consistency (Stability / Accuracy)

The determination of taste, shape, and texture that has been standardized is also important because in business it is not possible to sell products that are not fixed, but changeable. This will greatly affect consumers.

c. Texture / Form / Shape

Texture means the composition in a product that can be felt by the tongue, such as hard, soft, solid, liquid, etc.

Shape or cut means sliced or cut food served, can be round, square, and so on.

d. Nutritional content

Nutrient content contained in a food.

e. Visual appeal

The overall visual appeal of the product being sold is seen in the packaging.

f. Aromatic appeal

The aroma of a food will certainly vary. This is due to the content of the ingredients used in making food. This aroma will stimulate the sense of smell, namely the nose, then will be conveyed to the brain in the form of attraction or vice versa to the smell.

\section{g. Temperature}

The right temperature is recommended so that the product is in a very good state for consumption. For example, chicken noodles are recommended to be eaten while hot or warm. When it's cold, the water in the chicken noodles will be absorbed and make the noodles become mushy. In addition, the oil quality has decreased. (p. 159).

\subsection{Frozen Food}

Frozen food is food that has been through freezing for the purpose of preservation so that it becomes practical in the consumption phase.

According to nutritionist, Emilia E. Achmadi, in article tempo.co (2018), freezing methods can inhibit the growth of fungi and bacteria so that the food produced will last longer. In addition, the freezing method will not eliminate the nutritional value.

According to Ir. Ahmad Sulaeman, M.s., $\mathrm{Ph}$., A freezing method that is good and right 
can produce frozen food that lasts up to 1-3 months in a stable freezer temperature, which is $-17.7 \mathrm{oC}$. Although it can extend the shelf life of food, freezing at this temperature is unable to destroy the microorganisms that are in the food. However, it only slows its growth. The resistance of frozen food is very dependent on the type of material that is frozen so that different results will be obtained. Similarly, uli ketan differentiation can last up to three months at $-18 \mathrm{oC}$ after an experiment by the authors the quality of uli ketan is still in good condition.

\subsection{Product Differentation}

Uli ketan that is served on the market today requires a different taste, aroma, or appearance. In marketing activities known as product differentiation. Differentiation is a way of designing meaningful differences to distinguish a company's offer from its competitors' bids (Kotler and Susanto, 2001).

Product differentiation is an offer made by a company that has something of a distinguishing characteristic, such as lower prices, faster, and better which will create higher value in the eyes of consumers than competitors (Kotler, 2002, p. 2).

Kasumbogo Untung (in Yudhiarina, 2009: 2292) states that "Product differentiation is an innovative development effort. Usually responded positively by the buyer because they are considered to have better value and meet consumer tastes. "According to Rochmah (2014), product differentiation is an effort to produce similar goods, but differentiated by packaging, quality, brand, or color.

Based on the definition of experts, product differentiation is an effort in developing a product to have distinguishing features from competitors and usually this differentiation will be well received by buyers because they believe that products made will be more in accordance with the wishes of consumers. Product differentiation is a factor that is the focus to attract consumers.

According to Kotler (2007) differentiation can be divided into the following. a. Form

The shape of the product that is visible from the appearance, model, or physical structure of a product.

\section{b. Privileges}

The point is features that support the basic functions of the product so that the product is made better than its competitors.

c. Quality of Conformity

Products made in accordance with the needs and desires of consumers.

d. Durability

A measure of the lifetime of a product in good condition for consumption.

e. Reliability

The size of a product can be guaranteed from damage.

f. Impression of Style

The impression felt by consumers when consumers decide to use or consume products.

g. Design

The overall design of a product (p. 385).

\subsection{Packaging and labeling}

Packaging or packaging is a container or place that is used to protect a product from external threats that make the product quality has decreased, even damaged. Packaging is the process of designing and producing containers or packages for a product (Kotler and Keller, 2009: 27).

Packaging plays an important role for the product. The function of the packaging was initially limited to protecting the product or making it easier to retrieve goods. However, at present, packaging functions as an effective marketing tool of a product.

Good and attractive packaging can affect the purchase of a product. According to research by Brader (in Wildyana et al., 2006: 110). "Around 38 percent of consumers choose products because of packaging". In addition, Kodar (in Wildyana et al, 2006 110) revealed "Research in Europe shows that 74 percent of product purchases are due to packaging".

In designing packaging, you should pay attention to the following matters:

1) Suitability between the product and its packaging material;

2) Packaging size and material used;

3) Packing form.

\subsection{Product Selling Price}

Price is the amount of the price charged for the product or service or the amount of value exchanged by consumers for the benefits of owning or using the product or service (Kotler and Armstrong, 2012, p. 314).

Price is the amount of money needed to get a combination of goods and services (Swastha, 2005: 147). Meanwhile, according to 
Alma (2014, p. 169), the price is the value of an item expressed in money.

From the explanation of some of these experts, the author can conclude that the price is a value of money, including goods and services offered, to replace the ownership of an item and service to another party.

\subsection{Marketing Strategy}

According to Phillip and Kotler (1999), marketing strategy consists of making decisions about the marketing costs of the company, marketing mix, and marketing allocation. (p.9). Marketing strategy is a set of goals and objectives, policies, and rules that provide direction as a reference to the efforts made by the company from time to time, at each level, and reference allocation, especially in response to the company facing the environment and competition that is always changing (Assauri, 2013: 15).

Based on this description, marketing strategy is a way or plan prepared to achieve company goals.

The marketing strategy is the key to the company's success because effective and efficient marketing planning will result in profitable product sales for the company. According to a Maxmanroe.com article, there are broadly four functions of a marketing strategy, namely increasing motivation to see the future, coordinating marketing more effectively, formulating company goals, and overseeing marketing activities. Then, the aim is to improve the quality of coordination among individuals in the marketing team, as a measurement tool for marketing results based on predetermined achievements, as a logical basis in marketing decision making, and to improve the ability to adapt when changes in marketing occur.

\section{Materials and Methods}

\subsection{Subject and Object}

The subjects of this study, namely the writer and supervisor. The object of research is the differentiation of sticky rice. In this research, an experiment will be made to make products with the addition of red beans and oyster mushroom filling. The author wants traditional food, especially uli ketan, this can be developed even better so it is not easily excluded.

\subsection{Research Method}

The research method used is an experimental method by experimenting with product manufacture and trying to find the right recipe standard. The purpose of this study is that existing products are developed in such a way that they can display something different and better.

\subsection{Variable Operational}

Research variables are all things that can affect the value of the results set by the researcher to be studied and examined the value of the information so that a conclusion can be drawn (Sugiyono, 2008, p. 38). The variables tested were product quality from the product differentiation carried out, namely product differentiation, packaging techniques, and the marketing strategy undertaken.

\subsection{Experimental Design}

The research used was an experimental descriptive method with qualitative data, namely by analyzing the following four stages.

\subsubsection{Kitchen project}

Pre-research Kitchen Project in making fried rice sticky rice with variations in the addition of mushroom filling is done by the process of selecting sticky rice first, sticky rice used is the type of white sticky rice.

The sticky rice used comes from several selected markets. For a while, researchers bought rice at traditional markets in Bandung. Since the production process is still small, if the product is well received, the author plans to take sticky rice from agriculture in the Subang area. In making fried rice sticky rice cakes, try three sets that have been set.

a. UKKJ1 = Uli Sticky Mushroom Red Beans, $75 \%$ addition of red beans

b. UKKJ2 = Uli Sticky Mushroom Red Beans, $50 \%$ addition of red beans

c. UKKJ3 = Uli Sticky Mushroom Red Beans, $35 \%$ addition of red beans

Product testing will be seen from the product quality variable which consists of seven attributes, namely taste, permanence, texture, nutrition, appearance attractiveness, aroma, temperature (Marsum, 2005, p.159).

An assessment will be made of the product quality table as below. 
Table 1. Product Quality Assessment.

\begin{tabular}{|c|l|c|c|c|}
\hline \multirow{2}{*}{ No. } & \multirow{2}{*}{ Product Quality } & \multicolumn{3}{|c|}{ Rating Table } \\
\cline { 3 - 5 } & & UKKJ 1 & UKKJ 2 & UKKJ 3 \\
\hline 1 & Taste & $\ldots$ & $\ldots$ & $\ldots$ \\
\hline 2 & Consistency & $\ldots$ & $\ldots$ & $\ldots$ \\
\hline 3 & Texture & $\ldots$ & $\ldots$ & $\ldots$ \\
\hline 4 & Nutrient content & $\ldots$ & $\ldots$ & $\ldots$ \\
\hline 5 & Display & $\ldots$ & $\ldots$ & $\ldots$ \\
\hline 6 & Aroma & $\ldots$ & $\ldots$ & $\ldots$ \\
\hline 7 & Temperature & $\ldots$ & $\ldots$ & $\ldots$ \\
\hline & & $\ldots$ & $\ldots$ & $\ldots$ \\
\hline
\end{tabular}

source : processed data, 2020

\subsubsection{Packaging and Label Design}

The packaging and label design will be created using a design application. The author chose the application of Canva and Corel Draw in making designs and labels. This application is felt to provide several advantages compared to other applications because the features are easy to understand and have previously been studied by the author. The author will also make designs according to the packaging standards that apply to food. In designing a packaging and labeling design, of course there are requirements for making packaging and labeling that is good and right.

\subsubsection{Setting the Selling Price}

The author determines the selling price of the product using several formulas. First, calculate the food cost based on the standard recipe that the author has specified. Then, determine the selling price by taking the following percentage.

$\begin{array}{lc}\text { food cost } & 45 \% \\ \text { overhead } & 25 \% \\ \text { employed } & 15 \% \\ \text { Heat,Light and Power } & 8 \% \\ \text { Net Profit } & 7 \%+ \\ \text { Selling price } & 100 \%\end{array}$

\subsubsection{Determination of Marketing Strategies}

Determination of marketing strategies become the most important part in business. Careful marketing strategy planning is the key to achieving company success. The implementation of the marketing strategy is carried out by the following steps.

1. Market segmentation

2. Target market

\section{Differentiation and market position}

\subsection{Data Collection Techniques}

The techniques and data collection tools that the authors do as follows.

a. Literature study

Look for theories that contain information relevant to the problem and research variables so that they can support research. The data sought is in the form of theories related to research in the form of studies on tourism, gastronomy, traditional food, rice cookery, product differentiation, prices, product packaging, and others.

b. Interview

Looking for primary data by interviewing indirectly by giving several questions to respondents about saturation of uli ketan, for example searching for data about the general public's opinion of uli fried sticky rice from the age range of $8-65$ years.

\section{c. Observation}

Make observations directly on the object of research, namely uli ketan. Looking at the situation of the general public against uli ketan in Bandung and in the writer's area, namely Tasik Regency. The results of his observations were that there were no more uli ketan buyers than other similar snacks. In fact, people are more inclined to buy fast food compared to this traditional Uli food.

d. Pre-research questionnaire

Provide questionnaires in the form of several questions to respondents in order to obtain information for related research.

e. Study documentation

Documenting all activities done by the author so that the data is valid as physical evidence. This data was created to support the research process that actually happened like the process of making uli ketan differentiation.

f. Experimental

Conduct research on products made to achieve research objectives. The data will be sought in the form of results that will be obtained after conducting an experiment to make the differentiation of fried rice sticky rice with the addition of red beans and oyster mushroom filling

\section{Results and Discussion}

After repeated trials of uli sticky differentiation, the author can conclude that a superior product is seen based on aspects of 
product quality so that it can be established as the best prescription formula. The following is a table of product quality assessments according to Marsum (2005).

Table 2. Product Quality Assessment Results.

\begin{tabular}{|c|l|c|c|c|}
\hline \multirow{2}{*}{ No. } & \multirow{2}{*}{ Product Quality } & \multicolumn{3}{|c|}{ Rating Table } \\
\cline { 3 - 5 } & & UKKJ 1 & & \\
\hline 1 & Taste & 4 & 3 & 2 \\
\hline 2 & Consistency & 5 & 4 & 4 \\
\hline 3 & Texture & 5 & 4 & 4 \\
\hline 4 & Nutrient content & 3 & 3 & 2 \\
\hline 5 & Display & 5 & 5 & 2 \\
\hline 6 & Aroma & 4 & 4 & 4 \\
\hline 7 & Temperature & 5 & 5 & 5 \\
\hline \multicolumn{2}{|c|}{ Total } & 31 & 28 & 23 \\
\hline
\end{tabular}

source : processed data, 2020.

The following explanation of the results of the assessment of the experiments of the instrument.

The total UKKJ1 assessment results are 31 points. The following explanation is related to the assessment of the quality of UKKJ1 products. The resulting flavor is strong between red beans, mushrooms, and sticky rice. The consistency of each raw material used is a good and appropriate whole. The resulting texture is very fluffier, influenced by the amount of red beans used in the recipe formula. The appearance of uli ketan is made different from usual so that it makes this uli ketan more unique and interesting with its triangle shape. The resulting aroma is good and appetizing. The temperature of the food is very suitable as a snack food because it is served at a warm temperature, but not too hot and very delicious when consumed.

The results from UKKJ2 are 28 points. UKKJ2 has a red bean flavor that is strong enough in its uli ketan, combined with mushroom stuffing and sticky rice flavor to produce a delicious flavor. Consistency or stability of all good elements. The uli texture is fluffier, but not as smooth as UKKJ1. Attractive appearance with a flat round shape, but the shape is too wide to cause the impression of being full. The resulting aroma is appetizing. The temperature at the time of presentation is very fitting to be eaten as a snack.

UKKJ3 point results are 23 points. UKKJ3 has a red bean flavor that is less strong when compared to UKKJ1 and UKKJ2. The stability of all raw materials is good. The texture of uli ketan should be uli in general not fluffier. The display is less attractive because it is too big and elongated like in general. The resulting aroma is good. Presentation temperature is very fitting.

In the product quality attribute, according to Marsum, there are also aspects of nutritional content that must be assessed. Therefore, the authors have calculated the nutrient content of sticky rice in each recipe as follows.

The author calculates each 1 pcs consumption of sticky rice with differentiation, will provide nutritional intake as below:

1) UKKJ1 Fiber:

2) UKKJ2 Fiber:

3) UKKJ3 Fiber:

After assessing the nutritional content of the three recipes that the authors set, all recipes qualify as a snack food recommended by the doctor a maximum of 150 - 200 calories per each consumption and should have 10 grams of protein and 10 grams of fiber. UKKJ1 has greater calories, but its fiber and protein content is superior compared to $\mathrm{UKKJ} 2$ and $\mathrm{UKKJ} 3$. The UKKJ2 calorie is the second largest after UKKJ1 and has the same fiber and protein content as UKKJ1. The UKKJ3 calories are the least, but the protein and fiber are lower. This happens because of the effect of different red bean contents in the recipe formula.

Based on this assessment, the selected product was glutinous rice with $75 \%$ red beans (UKKJ1) from the quantity of glutinous rice. The UKKJ1 recipe is superior in terms of taste, consistency, and texture. Uli ketan with the addition of $75 \%$ red beans (UKKJ1) showed the expected results in this study due to several factors, namely the taste of uli ketan become more unique because the combination of red beans with uli ketan and mushroom fused into a new taste in the variant of uli ketan. Then, the resulting texture becomes very fluffier on the ulinya, then crunchy on the outer layer due to the addition of bread flour. The shape and portion of ketchup is not as usual because the author makes 1 portion weighing 50 grams and has a triangle shape. This is done so that the portion is sufficient as a snack food does not make it too full. The following are the results of the uli ketan experiment with the addition of red beans and oyster mushroom filling. 


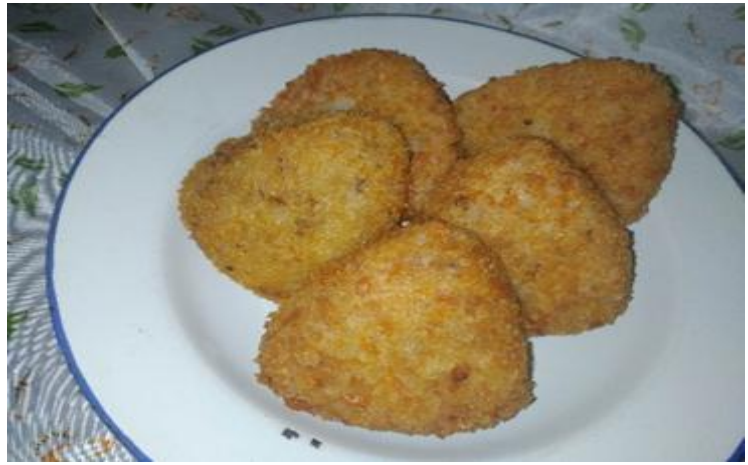

Figures 1. Uli ketan diferensiasi source : processed data, 2020.

\subsection{Recipe Formulation}

Table 3. Recipe formulation

\begin{tabular}{|c|c|c|c|}
\hline \multicolumn{2}{|c|}{ Fried O.Sativa Glutinosa } & \multicolumn{2}{|c|}{90 menit } \\
\hline \multicolumn{2}{|c|}{27 Portion } & \multicolumn{2}{|c|}{$\begin{array}{l}\text { Stir-fry and } \\
\text { steamed }\end{array}$} \\
\hline NO & INGREDIENTS & QTY & UNIT \\
\hline 1 & Sticky rice & 320 & gr \\
\hline 2 & Grated coconut & 85 & gr \\
\hline 3 & Salt & 8 & gr \\
\hline 4 & Oil & 50 & $\mathrm{ml}$ \\
\hline 5 & Kidney bean & 225 & gr \\
\hline \multicolumn{4}{|c|}{ Filling } \\
\hline 6 & Oyster mushroom & 750 & $\mathrm{Gr}$ \\
\hline 7 & Balado seasoning & 100 & $\mathrm{Gr}$ \\
\hline 8 & Chili & 20 & $\mathrm{gr}$ \\
\hline 9 & Orange leaf & 5 & lmbr \\
\hline 10 & Mozzarella cheese & 100 & gr \\
\hline 11 & Carrot & 150 & gr \\
\hline 12 & Salt & 8 & gr \\
\hline 13 & Sugar & 6 & gr \\
\hline 14 & Oil & 50 & $\mathrm{ml}$ \\
\hline 15 & Shallot & 20 & gr \\
\hline 16 & Garlic & 10 & $\mathrm{gr}$ \\
\hline 17 & Pepper & 5 & gr \\
\hline \multicolumn{4}{|c|}{ Finishing } \\
\hline 18 & Bread crumbs & 250 & $\mathrm{gr}$ \\
\hline 19 & Eggs & 2 & pcs \\
\hline 20 & Water & 50 & $\mathrm{ml}$ \\
\hline \multicolumn{4}{|c|}{ Equipment \& tools need } \\
\hline 1 & \multicolumn{3}{|l|}{ Refrigerator 1} \\
\hline 2 & \multicolumn{3}{|l|}{ Magicom 1} \\
\hline 3 & \multicolumn{3}{|l|}{ Two fire gas stove 1} \\
\hline 4 & \multicolumn{3}{|l|}{ Knife 1} \\
\hline
\end{tabular}

\begin{tabular}{|c|c|c|c|}
\hline \multicolumn{2}{|c|}{ Fried O.Sativa Glutinosa } & \multicolumn{2}{|c|}{90 menit } \\
\hline \multicolumn{2}{|c|}{27 Portion } & \multicolumn{2}{|c|}{$\begin{array}{c}\text { Stir-fry and } \\
\text { steamed }\end{array}$} \\
\hline NO & INGREDIENTS & QTY & UNIT \\
\hline 5 & \multicolumn{3}{|l|}{ Cutting board 1} \\
\hline 6 & \multicolumn{3}{|l|}{ Bowls 3} \\
\hline 7 & \multicolumn{3}{|l|}{ Tampah 1} \\
\hline 8 & \multicolumn{3}{|l|}{ Rice spoon 2} \\
\hline 9 & \multicolumn{3}{|l|}{ Plastic bag 10} \\
\hline 10 & \multicolumn{3}{|l|}{ Container 2} \\
\hline 11 & \multicolumn{3}{|l|}{ Spatula 1} \\
\hline 12 & \multicolumn{3}{|l|}{ Pan 1} \\
\hline 13 & \multicolumn{3}{|l|}{ Blender 1} \\
\hline \multicolumn{4}{|c|}{ How to make : } \\
\hline 1. & \multicolumn{3}{|c|}{ Chopped Mushrooms and carrots } \\
\hline 2. & \multicolumn{3}{|c|}{ Prepare balado seasonings } \\
\hline 3. & \multicolumn{3}{|c|}{ Stir on red and white onion } \\
\hline \multicolumn{4}{|c|}{ 4. Add mushrooms } \\
\hline 5. & \multicolumn{3}{|c|}{ Put balado seasoning } \\
\hline \multicolumn{4}{|c|}{$\begin{array}{l}\text { Cook until the water contained in the mushrooms } \\
\text { shrinks (Set aside in a container) }\end{array}$} \\
\hline \multicolumn{4}{|c|}{ Wash the rice soaked rice that has been soaked } \\
\hline \multicolumn{4}{|c|}{ 8. Steamed sticky rice for about 20 minutes } \\
\hline \multicolumn{4}{|c|}{ 9. Add grated coconut, salt, kidney beans } \\
\hline \multicolumn{4}{|c|}{ 10. Prepare pestle and tampah } \\
\hline \multicolumn{4}{|c|}{ 11. Mash until the ingredients are steamed } \\
\hline \multicolumn{4}{|c|}{ 12. Form and add fields } \\
\hline \multicolumn{4}{|c|}{ 13. Prepare bread crumbs with eggs. } \\
\hline \multicolumn{4}{|c|}{ 14. cover ulen and spread bread flour } \\
\hline \multicolumn{4}{|c|}{ 15. Put it in the package or fried } \\
\hline
\end{tabular}
source: processed data, 2020.

\subsection{Packaging and labeling}

The results of the packaging used are plastic vacuum and mica boxes labeled. Vacuum plastic is used so that the product is safer and maintained its quality, while mica as an outer layer and aesthetic enhancer in packaging. In the packaging results will be listed the nutritional value of sticky rice products as the following table. 
Table 5. Nutritional value information

\begin{tabular}{|c|c|c|}
\hline \multicolumn{3}{|c|}{$\begin{array}{l}\text { NUTRIENT VALUE INFORMATION } \\
\text { Portion } 50 \mathrm{gr} \\
\text { Served per pieces } 5 \text { pak }\end{array}$} \\
\hline \multirow[t]{2}{*}{$\begin{array}{l}\text { Portion } \\
\text { Total Energy } \\
\text { (Calories) }\end{array}$} & $134 \mathrm{kkl}$ & \\
\hline & & $\% \mathrm{RDA}$ \\
\hline Fat & $7 \mathrm{gr}$ & $11 \%$ \\
\hline Protein & $5 \mathrm{gr}$ & $7 \%$ \\
\hline Carbohydrat & $15 \mathrm{gr}$ & $5 \%$ \\
\hline Fiber & $3 \mathrm{gr}$ & \\
\hline Sugar & $2 \mathrm{gr}$ & \\
\hline Sodium & $379 \mathrm{mg}$ & \\
\hline Kalium & $277 \mathrm{mg}$ & \\
\hline
\end{tabular}

source : processed data, 2020

After packaging design, the results obtained are as follows. The selected packaging is vacuum plastic and mica packaging. Mica packaging was chosen because the price is affordable and quite attractive.

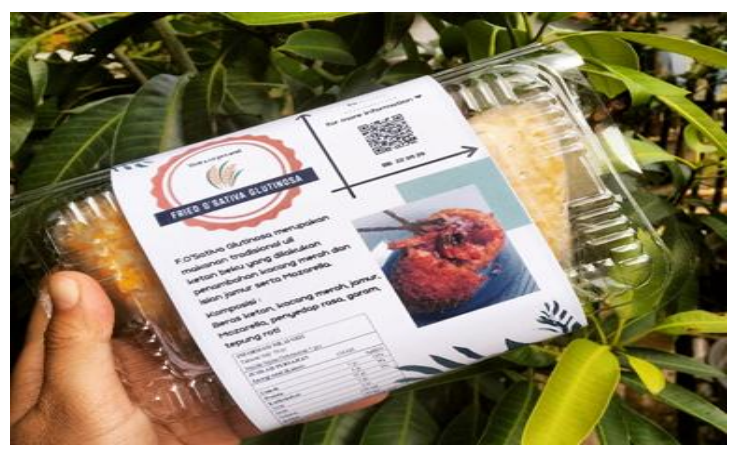

Figures 2. Uli ketan Packaging

source : processed data, 2020

\subsection{Selling Price Determinant}

After the product was selected, Uli Goreng Goreng with the addition of $75 \%$ red beans and oyster mushroom filling, the selling price was determined.

The author has determined all cost details by taking the percentage as follows.

food cost

$45 \%$

overhead

$25 \%$

employed

Heat,Light and Power
Total staple raw materials (45\%)Rp43.197

Overhead (25\%) Rp23.998

Employed (15\%) Rp14.399

Heat,Light and Power (8\%) Rp 7.679

Net profit (7\%) Rp 6.719

Selling price (100\%) Rp95.993

Selling price/portion Rp 3.600

Net Profit $7 \%+$ Selling price $100 \%$

To determine the selling price in the table above, the formula is used:

$\mathrm{SP}=100 \% / \%$ foodcost $\mathrm{x}$ Foodcost total

Based on the recipe formulation, the price of the basic raw material is Rp.43,197.00. If in one production there are 27 portions, the basic price per unit is Rp1,600, 00 the selling price when taking $45 \%$ food cost:

$\mathrm{SP}=100 \% / 45 \% \times 1600=3.555 / \mathrm{pak}$

In addition to sold mature union, the author wants to sell per pack of frozen contents 5 pcs. So, the selling price becomes $=5 \mathrm{x}$ Rp3,600 = Rp18,000.00 / pack

The price specified does not include adjustments to other factors, the price may be adjusted if the marketing conditions change.

\subsection{Marketing Strategy}

In accordance with the strategic planning in the previous chapter the author designed that

a. Market segmentation

The market segmentation that the authors have determined geographically is Java Island Indonesia, but, initially, it will be developed specifically in the West Java area. Demographic segmentation, Fried O.Sativa Glutinosa targets all people and genders. And psychographically Fried O.Sativa Glutinosa is intended for middle social classes, but can be for the middle to lower classes.

b. Determination of target markets

Products sold in the form of traditional foods are differentiated, including the snack food category. The target location is major cities on the island of Java that can be reached by couriers for a maximum of 1-2 business days. The target market is seen from the vulnerable age are those aged between 16-45 years. However, it is focused on adolescents to middle phase adults. Other than that, the target market of this product, when viewed from a 
psychological perspective, is people who are familiar with the internet and social media and consumer trends such as spending time in cafes or restaurants.

\section{c. Differentiation and market position}

Differentiation is carried out visible from the product, packaging, and packaging methods used. This differentiation is expected to be well received by the community. The author made this differentiation because he wanted to help in developing traditional Uli foods which slowly began not to be chosen by the community.

d. Product differentiation

Product differentiation is carried out by adding other ingredients in the recipe of uli ketan. The author added red beans and mushroom stuffing and was given bread flour in the outer layer. This will affect the taste, texture, appearance / shape, as well as the nutritional content in sticky rice as explained in point 4.1 number 1 . The addition of red beans and oyster mushrooms is done because the processing of these ingredients is used less often for business than other ingredients such as meat chicken. In addition, these ingredients also have high enough fiber and protein content so that they are expected to help meet the nutritional requirements of glutinous rice. Another thing that makes uli ketan is more interesting to be developed because this keti sticky rice is included in the category of traditional Indonesian food snacks market snacks.

\section{e. Packaging differentiation}

Typically, traditional Uli ketan packaging has a very simple form of packaging, such as wrapped in a banana leaf or in mica plastic and added to a banana leaf, even street vendors only use a piece of brown rice paper to wrap it up, are less attractive, and sell. As it is known that the function of packaging is very important as a product marketing tool to attract the attention of consumers. It would be nice if traditional food packaging also received serious attention to support traditional Indonesian products. Therefore, the author wants to do the differentiation in terms of packaging. The packaging that I will make is to use frozen plastic and mica boxes as the outer wrapper. Then, labeling the product label is done as well as a marketing tool for product introduction and as a product seal

f. Differentiation of packaging methods

The packaging method differentiation is also different from the usual, namely the freezing method. This method was chosen because with freezing, the product can last longer. Typically, glutinous rice only lasts at room temperature for 2-3 days with the product freezing method can last a maximum of three months in a stable freezer temperature of -18 .

The positioning of uli ketan differentiation products is as a traditional snack food that is chosen because of the uniqueness of its products in terms of taste, appearance, branding, style or style. The author wants to position the product as selected snack products in places to hang out, such as in a coffee shop or coffee shop. Want to show the impression that this traditional food is delicious and has a good impression when consumed. Want to show the proud impression of consumers' minds because of the appearance given.

The following efforts will be made by the author.

1) Product Strategy

The product strategy is carried out as follows. Always maintain product quality by applying prescription standards; Maintain the uniqueness of the product so that it is difficult to be imitated by competitors; Continue to evaluate the shortcomings of the products made according to market developments; Add new variants, such as new flavors and variations;

2) Pricing Strategy

The pricing strategy used by Fried Sativa O.Glutinosa is to apply competitive prices on the market. This is done as a first step in sales.

3) Distribution Strategy

Distribution strategy in this business is to involve courier expeditions as a supporting media in product distribution. In addition, the authors want this product to be distributed to several coffee shops.

4) Promotion Strategy

In business planning, an important key to success is the promotion strategy. The author strongly emphasizes promotion in marketing this product. Promotions that will be carried out are branding the product so that consumers feel proud to buy products that are made and feel psychological satisfaction from the display offered. In addition, the promotion to be carried out is a discount when making a minimum purchase.

\section{Conclusions}

After conducting research based on the formulation of the problem made by the author, 
it can be concluded the following.

The most desirable recipe formulation is the UKKJ1 recipe formulation by adding 225 grams of red beans and oyster mushroom filling. This greatly influences the taste and texture of the uli ketan because red beans complement the taste of glutinous rice coupled with savory spicy oyster mushrooms making a new color from the taste of this sticky rice product. In addition, the nutritional value of sticky rice that has undergone this differentiation also increased can be seen in table 4.6. Furthermore, the texture of the uli produced becomes more fluffier and different from the uli ketan in general. This is good news that traditional food can be made more varied so that it is more interesting and prevents boredom about the traditional food. The packaging and labeling used are plastic vacuum and mica boxes. The label used will be simpler than the packaging. The design of the packaging and labeling is done as an effort so that traditional food can be packaged better. Good packaging will greatly affect the product, both in maintaining quality and as the most important marketing tool so that customers are interested in buying.

The selling price of uli ketan, named Fried O.Sativa Glutinosa, will be priced at Rp. $18,000.00$ / pack, with 5 pcs uli ketan in each packet and Rp. 4,000 for each cooked unit price. This price is the initial price during the promotion period and in the future there will be price adjustments.

The marketing strategy undertaken is to segment and target the market because this product is intended for all groups, from the lower classes to the top. In addition, the strategy taken is to work with coffee shops. Brand development will also be carried out. This uli ketan product also establishes its market position as a selected traditional snack and it is hoped that consumers will have a sense of pride in Indonesian local products.

\section{Acknowledgment}

The compilation of this journal is inseparable from extraordinary people who help the writer. For guidance or guidance from various groups, I express my deepest gratitude to the parties concerned. I say this thank you to the honorable:

a. Chancellor of the Indonesian University of Education who has given the opportunity to the writer as a UPI student. b. Head of the Faculty of Social Sciences Education who has provided the opportunity for writers to complete this journal.

c. Dr. Dewi Turgarini, MM.Par as Chairperson of the Department of Catering Industry Management who has given permission and time to research this journal.

d. Ms. Woro Priatini, S.Pd., M.Sc. as the first advisor in this research. He is very kind, sincere, and caring and caring in providing guidance and direction for the completion of this journal. Thank you very much

e. Mr. Ridwan Iskandar, S.E., M.M., as the second mentor, who has guided and taught me clearly and fluently so that it is very helpful for me to understand in working on this journal. Thank you very much for your knowledge, attention and advice.

Hopefully this journal is useful for readers to realize that this journal is far from perfect. Therefore, constructive criticism and suggestions from readers, the writer hopes for the perfection of this journal.

\section{References}

Katsoni, Vicky dkk. Cultural and tourism Innovation In the Digital Era:Sixth International IACuDiT Conference, Athens 2019. Athens: Springer nature

Intani T, Ria. 2014. Kiat Penjual Makanan Tradisional Dalam Menembus Pasar. Palanja., 16(2), hlm 186.

Hall, C Michael., Mitchell, Richard. (2006). Gastronomy, food, and wine tourism, Tourism Business Frortiers, consumer product dang industry, Elsevier, Edited by Dimitrios Buchales and Carlos Costa

Turgarini, Dewi. (2016). Gastronomy Tourism Attraction in Ternate City. Advances in economy and management research Atlantis Press, 18, hlm 91.

Muhilal. (1995). Makanan Tradisional sebagai Sumber Zat Gizi dan Non Gizi dalam Meningkatkan Kesehatan Individu dan Masyarakat. Widyakarya nasional Khasiat Makanan Tradisional, 9-11

Moeriabrata, Arsani, Arbei. (1997). Makanan tradisional makna sosial budaya dan manfaatnya sebagai makanan sehat ('Function Food") dan upaya pelestariannya. Surabaya : Airlangga 
University Press

Agustine P, Fira. (2019). Mengulik Sejarah Pembuatan Ketan Uli yang Romantis. htpp://m.ayobekasi.net/read/2019/11/12/ 4200/mengulik-sejarah-pembuatan-ketan -uli-yang-romantis (diakses 14 mei 2019)

Priyanto. (2012). Beras ketan dan sifat fisika kimianya.

http://www.alatcetakrangginang.com/201 2/02/beras-ketan-sifat-fisika-kimianya.ht ml. (diakses 17 maret 2020)

Suriani. (2015). Analisis Proksimat pada beras ketan varietas putih. Alkimia, 92

Sandep Kumar, et al. (2012). Clinical complications of red kidney bean (Phaseolus Vulgaris L) comsuptions. Nutrient journal, hlm.1

Bender, A. E. dan Reaidi, G. B. (1982). Toxicity Of Kidney Beans (Phaseolus Vulgaris L) With Particular Reference To Lectins. Journal Plants and Foods 4, 15-22

Piska, Kamil, Sułkowska-Ziaja, Katarzyna. dan Muszyńska, Bożena. (2017). Edible mushroom Pleurotus ostreatus (Oyster mushroom) - Its Dietary Significance And Biological Activit. Acta Sci. Pol. Hortorum Cultus, 16(1) 2017, 151-161

Widyastuti, Netty. (2013). Pengolahan Jamur Tiram (Pleurotus Ostreatus) sebagai Alternatif Pemenuhan Nutrisi. JSTI : Pengolahan Jamur Tiram, 15(3), 1

Jhon C. (2006). Contemporary Quantity Recipe File United States of America: Cahners Books

Cristine, Amy B (2014). Understanding Food: Principles and Preparation United States of America: Cengage Learning

Payne, June P. (2009). Introduction to Food Service. United States of America: Pearson Prentice Hall

Kotler., dan Keller. (2009). Manajemen Pemasaran. Jilid I Edisi 13 Jakarta: Erlangga

Handoko, T. Hani. (2002). Manajemen Pemasaran. Jakarta: IPWI

Arumsari, Dheany. (2012). Analisis pengaruh produk, Harga, Promosi terhadap keputusan pembelian air minum dalam kemasan (AMDK) Merk Aqua. Semarang : Universitas Diponegoro Semarang
Marsum, WA. (2005). Restoran dan Segala Permasalahannya. Yogyakarta: Andi

Davies, Anastasia Pramudita. (2018). Makanan Beku Lebih Sehat dari Makanan Biasa? Ini kata Ahli Gizi. https://gaya.tempo.co/1087245/makananbeku-lebih-sehat-dari-makanan-biasa-?-i ni-kata-ahli-gizi (diakses 25 juli 2019)

Kotler, Philip dan A.B Susanto. (2001). Manajemen Pemasaran di Indonesia: Analisis Perencanaan Implementasi dan Pengendalian. Jakarta: Salemba Empat

Kotler, Phillip. (2002). Marketing Places. Simon and Schuster

Yudhiarina, Bobby. (2009). Pengaruh Strategi Diferensiasi Produk, Merk, dan promosi terhadap proses keputusan pembelian konsumen pada perusahaan rokok PT. HM. Sampoerna. Jurnal Ichsan Gorontalo 4(2)

Kotler, Phillip. (2007). Marketing Management. pearson italia Spa

Wildyana, P. Tommy Y. S Suyasa. (2006). Persepsi dalam Kemasan dan Intensi Membeli. Phronesis Jurnal Ilmiah Psikologi Industri dan Organisasi, 8(2), 110-124

Gary, Amstrong., dan Kotler, Phillip. (2012). Marketing management 13. New Jersey : Pearson Preactice hall inc

Swastha, Basu., dan Irawan. (2005). Manajemen Pemasaran Modern. Yogyakarta: Liberty

Alma, Buchari. (2014). Manajemen Pemasaran dan Pemasaran Jasa. Bandung: ALFABETA

Kotler, Phillip. (1999). Marketing Management: The Millenium Edition. Prentice Hall

Assauri, Sofjan. (2013). Manajemen Pemasaran. Jakarta: Rajawali Pers

maxmanroe.com. Strategi pemasaran: pengertian, fungsi, tujuan, konsep dan contohnya.https://

www.maxmanroe.com/vid/marketing/pe ngertian-strategi-pemasaran.html (diakses 28 maret 2020)

Sugiyono. (2009). Metodologi Penelitian Pendidikan. Bandung : Alfabeta

Sugiyono. (2008). Metode Penelitian Pendidikan: pendekatan Kuantitatif, Kualitatif dan $R \& D$. Bandung: Alfabeta. 


\section{Appendix 1. Uli Ketan Price}

Table 6. Uli Ketan Price

\begin{tabular}{|c|c|c|c|c|c|}
\hline NO & INGREDIENTS & QTY & UNT & UNIT PRICE & TOTAL PRICE \\
\hline 1 & Sticky rice & 320 & gr & $14000 / \mathrm{kg}$ & Rp4.480 \\
\hline 2 & Grated coconut & 85 & gr & 7000/item & Rp2.380 \\
\hline 3 & Salt & 8 & gr & $14000 / 500 \mathrm{gr}$ & Rp224 \\
\hline 4 & Oil & 50 & $\mathrm{ml}$ & $20500 / 21 \mathrm{t}$ & Rp513 \\
\hline 5 & Kidney bean & 225 & gr & $30000 / 1 \mathrm{~kg}$ & Rp6.750 \\
\hline \multicolumn{6}{|l|}{ Isian } \\
\hline 6 & Oyster mushroom & 750 & gr & $7000 / 500 \mathrm{gr}$ & Rp3.500 \\
\hline 7 & Balado seasoning & 100 & gr & $7000 / 50 \mathrm{gr}$ & Rp4.667 \\
\hline 8 & Chili & 20 & gr & $5000 / 100 \mathrm{gr}$ & Rp333 \\
\hline 9 & Orange leaf & 5 & $1 \mathrm{mbr}$ & $100 / \mathrm{pcs}$ & Rp167 \\
\hline 10 & Mozzarella cheese & 100 & gr & $35000 / 200 \mathrm{gr}$ & Rp5.833 \\
\hline 11 & Carrot & 150 & gr & $3000 / 250 \mathrm{gr}$ & Rp600 \\
\hline 12 & Salt & 8 & gr & $14000 / 500 \mathrm{gr}$ & Rp75 \\
\hline 13 & Sugar & 6 & gr & $28000 / 1 \mathrm{~kg}$ & Rp93 \\
\hline 14 & Oil & 50 & $\mathrm{ml}$ & $20500 / 21 \mathrm{t}$ & Rp171 \\
\hline 15 & Shallot & 20 & gr & $5000 / 100 \mathrm{gr}$ & Rp333 \\
\hline 16 & Garlic & 10 & gr & $5000 / 100 \mathrm{gr}$ & Rp83 \\
\hline 17 & Pepper & 5 & gr & $1000 / 7 \mathrm{gr}$ & Rp4.762 \\
\hline \multicolumn{6}{|c|}{ Uli Coating } \\
\hline 18 & Bread crumbs & 250 & $\mathrm{Gr}$ & $5000 / 250 \mathrm{gr}$ & Rp5.000 \\
\hline 19 & Eggs & 2 & pcs & $1500 / \mathrm{pcs}$ & Rp3.000 \\
\hline 20 & Water & 50 & $\mathrm{Ml}$ & $2800 / 600 \mathrm{ml}$ & Rp233 \\
\hline \multicolumn{5}{|c|}{ Total staple raw materials ( $45 \%)$} & Rp43.197 \\
\hline & & & & Overhead $(25 \%)$ & Rp23.998 \\
\hline \multirow{2}{*}{\multicolumn{5}{|c|}{$\begin{array}{r}\text { Employed(15\%) } \\
\text { Heat,Light and Power }(8 \%)\end{array}$}} & Rp14.399 \\
\hline & & & & & Rp 7.679 \\
\hline \multicolumn{5}{|c|}{ Net profit(7\%) } & Rp 6.719 \\
\hline \multicolumn{5}{|r|}{ Selling price $(100 \%)$} & Rp95.993 \\
\hline \multicolumn{5}{|r|}{ Selling price/portion } & Rp 3.600 \\
\hline
\end{tabular}

